\title{
In vitro Efficacy of Bio Control Agents against Cotton Leafhopper, Amrasca biguttula biguttula (Ishida) (Homoptera: Cicadellidae)
}

\author{
A. Manivannan, R. Philip Sridhar, A. Kamalakannan*, \\ N. Ganapathy and S. Karthikeyan
}

${ }^{1}$ Department of Agricultural Entomology, ${ }^{2}$ Department of Plant Pathology, Centre for Plant Protection Studies, Tamil Nadu Agricultural University, Coimbatore-641003, Tamil Nadu, India

*Corresponding author

\section{A B S T R A C T}

\section{Keywords}

M. anisopliae, $B$

bassiana, L. lecanii, $C$. zastrowii, Leafhopper,

Cotton

Article Info

Accepted:

12 August 2018

Available Online:

10 September 2018
The bio efficacy of selected bio control agents viz. Metarhizium anisopliae, Beauveria bassiana, Lecanicilium lecanii and Chrysoperla zastrowii against Amrasca biguttula biguttula was studied under insectary, Department of Agricultural Entomology, TNAU, Coimbatore, India during 2014-2015. Three different concentrations viz., $1 \times 10^{4}, 1 \times 10^{6}$, $1 \times 10^{8}$ spore/ml of these each entomopathogenic fungus were tested to evaluate the effective concentration. Among the three concentrations, $1 \times 10^{8}$ spores $/ \mathrm{ml}$ of L. lecanii recorded the highest mortality of $85.00 \%$ against leafhopper withLT ${ }_{50}$ value of 115.37 hours and low $\mathrm{LC}_{50}$ value observed in L. lecanii $\left(1.83 \times 10^{4}\right.$ spores $\left./ \mathrm{ml}\right)$. In pot cultures studies, Among the bio-control agents, L. lecanii was the most effective in reducing cotton leafhoppers with average per cent mortality of 69.17 followed by C. zastrowii, B. bassiana and fungi combination with average per cent mortality of 55.83, 48.33 and 46.67 respectively.

\section{Introduction}

Cotton is an important natural fibre crop cultivated in varying climatic conditions of tropics as well as sub-tropic regions of more than 110 countries all over the world. Cotton plays a key role in the national economy in terms of generation of direct and indirect employment in the Agricultural and Industrial sectors. Among the various causes of low productivity of cotton in India, insect pests are one of the major factors. During growth period, 148 insect pests have been recorded on cotton crop, of which only 17 species were recorded as major insect pests (Abbas, 2001). Leafhopper undoubtedly is more severe among the many destructive pests of cotton. Cotton jassid is reported to cause 18.78 per cent decline in cotton yield (Ali, 1992). Both nymph and adult stages can destroy the plants by not only sucking into the leave tissues but also by transmitting different viruses, resulting in yield loss. The simple method being practiced for the control of insect pest, on which farmers frequently rely, is the chemical control (Arif et al., 2007). Chemical control 
not only creates health hazards and ecological contamination but also induces the resistance in insects and disturbing the balance between the forces of destruction (predators, parasitoids and pathogens) and forces of creation (biotic potential of pests) in agroecosystem (Ahmad and Khan, 1991; Sorejani, 1998). When this ecological balance is disrupted, potential insect pests are relived from the resistance imposed by their natural enemies and therefore, unhindered- population growth resulted in pest outbreak. In order to overcome these problems, application of biocontrol agents is a better option and thus forms integral part of IPM.

\section{Materials and Methods}

The present investigation was carried out at the insectary, Department of Agricultural Entomology, Tamil Nadu Agricultural Entomology, Coimbatore during 2014-2015. Entomopathogenic fungi viz. Metarhizium anisopliae, Beauveria bassiana and Lecanicilium lecanii were tested against cotton leafhopper, Amrasca biguttula biguttula at different concentration. Leafhopper culture was maintained on cotton plants grown in the pots under mylar thin film cage. The final instar nymphs of leafhoppers were collected from cotton field with the help of aspirator and released to cotton plants under mylar thin film cage and allowed for multiplication. Thus culture of leafhopper was maintained throughout the investigation period. Entomopathogenic fungi suspensions with different spore concentration of $1 \times 10^{4}, 1$ x $10^{6}$ and $1 \times 10^{8}$ spores $/ \mathrm{ml}$ were used for the pathogenicity test. The suspensions of selected entomopatogenic fungi were treated on the cotton leaves at different concentration and the treated cotton leaves were fed to the starved leafhopper from the lower surface of mylar thin film micro cage since the leafhopper always move upward direction. Six replications were maintained with 10 leafhoppers per replication. Untreated control was maintained simultaneously. Observations on nymphal or adult mortality were recorded in 24 hours interval up to eight days. This study was conducted at room temperature of $28^{\circ} \mathrm{C} \pm 2^{\circ} \mathrm{C}$.

Pot culture studies were conducted by using selected suspension from bio-efficacy studies. Different bio control agents were assessed for their efficiency in controlling A. biguttula biguttula incidence in cotton plant under laboratory conditions. The mylar thin film was used to design circularly and upper side was covered with muslin cloth with the help of stapler pin. This mylar thin film cage were caged over the cotton plants under the pots. Ten leafhoppers were collected from culture and released in to these each pots. After releasing, different bio control agents were imposed by using Completely Randomized Design (CRD) with four replications. Observations on nymphal or adult mortality were recorded in 24 hours interval up to fifteen days.

\section{Results and Discussion}

From the bioassay, a linear relationship between per cent mortality and dose was observed. In the bioassay with $M$. anisopliae, $B$. bassiana and L. lecanii against cotton leafhopper, the per cent mortality increased from 36.66 to $53.33,38.33$ to 71.66 and 50.00 to 85.00 per cent respectively at the dose concentration of $1 \times 10^{4}, 1 \times 10^{6}$ and $1 \times 10^{8}$ spore $/ \mathrm{ml}$ (Table 1 ). The susceptibility of target insect to fungal infection is dose dependent (Liu et al., 2002; Wright et al., 2005). Ansari et al., (2004) also found that mortality depended on the concentration of conidial suspension, exposure time and temperature. Among the three concentrations tested, $1 \times 10^{8}$ spore/ml recorded the highest mortality and $1 \times 10^{4}$ spore/ml recorded the lowest mortality of cotton leafhopper. The highest mortality of 
leafhopper $(85.00 \%)$ was recorded in $L$. lecanii of $1 \times 10^{8} \mathrm{spore} / \mathrm{ml}$. This was followed by $B$. bassiana $(71.66 \%)$. The lowest efficacy was recorded in $M$. anisopliae with mortality rate of 53.33 per cent. Karthikeyan and Selvanarayanan (2011), who reported efficacy of Beauveria bassiana with percent mortality against $H$. armigera $(86.67 \%)$, S. litura $(86.67 \%), \quad$ E. vittella $(73.33 \%)$ and Verticillium lecanii with percent mortality against A. gossypii (100.00 \%), B. tabaci $(100.00 \%)$ and A. devastans $(93.33 \%)$ at the concentration of $1 \times 10^{8}$ spores $/ \mathrm{ml}$.

Among the three entomopathogenic fungi,, low $\mathrm{LC}_{50}$ value observed in $L$. lecanii $\left(1.83 \times 10^{4}\right.$ spores $\left./ \mathrm{ml}\right)$ followed by B. Bassiana $\left(6.06 \times 10^{5}\right.$ spores $\left./ \mathrm{ml}\right)$ and highest $\mathrm{LC}_{50}$ value observed in $M$. Anisopliae $\left(1.52 \times 10^{7}\right.$ spores $\left./ \mathrm{ml}\right)$ (Table 1$) . \quad \mathrm{LT}_{50}$ value entomopathogenic fungi, low $\mathrm{LT}_{50}$ value was observed in L. lecanii (115.37 hours) followed by B. bassiana (164.18 hrs) and M. anisopliae (210.21hrs) with concentration of $1 \times 10^{8}$ spores $/ \mathrm{m}$ land maximum $\mathrm{LT}_{50}$ was observed in M. anisopliae (300.39hours) with concentration of $1 \times 10^{4}$ spores $/ \mathrm{ml}$ (Table 2). El-Sinary (2002); Quesada-Moraga et al., (2006) explained that the efficiency of the entomopathogenic fungi began clearly $48 \mathrm{~h}$ after inoculation and the hyphae penetrated the integument, epithelial and epidermal cells. After $72 \mathrm{~h}$, the fat tissues were damaged and mortality reached 100 per cent after $96 \mathrm{hrs}$.

Fig.1 Per cent reduction over control against cotton leafhopper with different bio control agents and chemical treatments under in-vitro condition

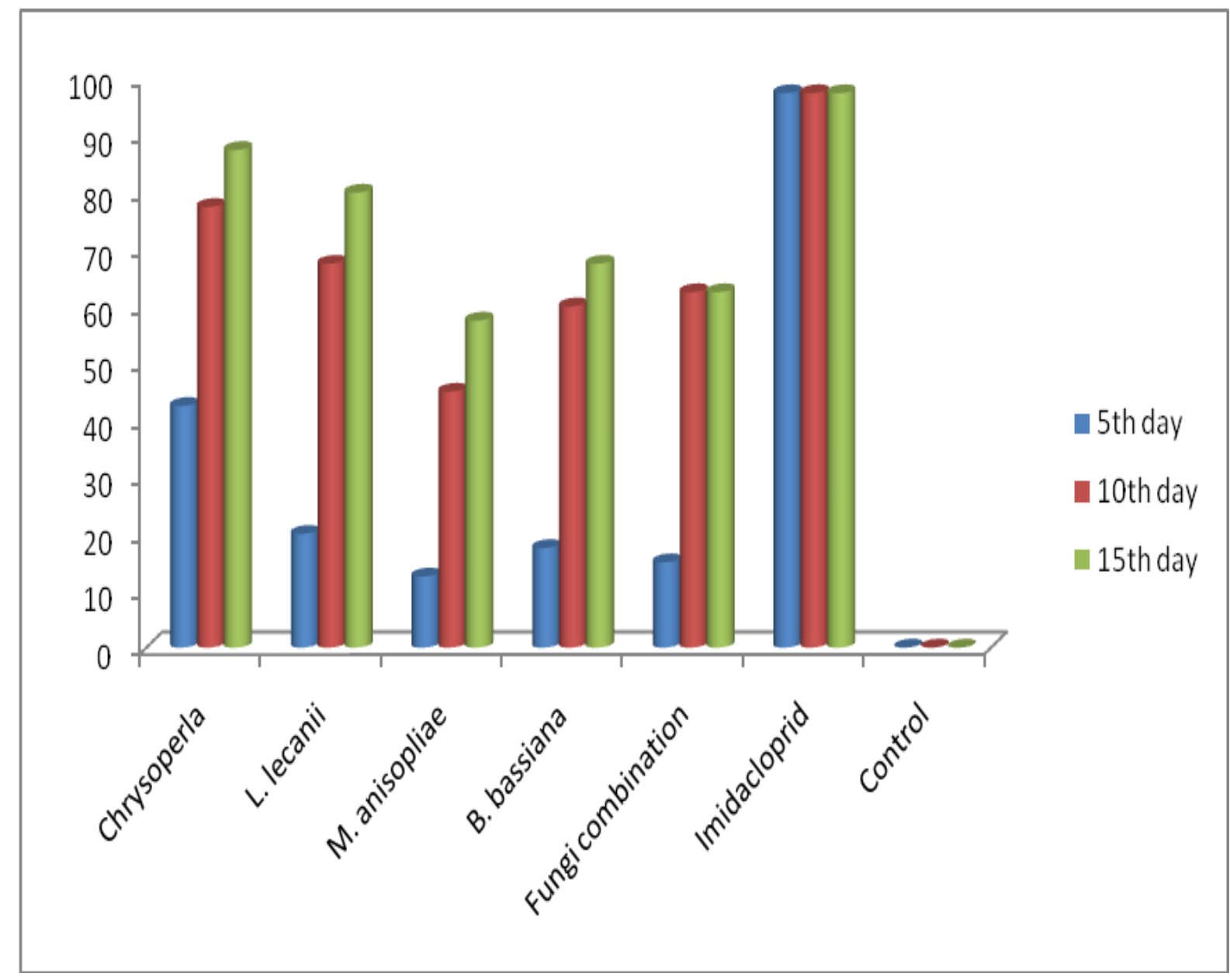


Table.1 Dose mortality response of entomopathogenic fungi against $A$. biguttula biguttula

\begin{tabular}{|c|c|c|c|c|c|}
\hline \multirow{2}{*}{$\begin{array}{c}\text { Entomopathogenic } \\
\text { fungi }\end{array}$} & \multirow{2}{*}{$\begin{array}{c}\text { Conidial } \\
\text { concentration } \\
\text { (Spores/ml) }\end{array}$} & \multirow{2}{*}{$\begin{array}{c}\text { Percent } \\
\text { mortality up } \\
\text { to } 8 \text { days }\end{array}$} & \multirow[t]{2}{*}{$\mathrm{LC}_{50}($ Spores/ml $)$} & \multicolumn{2}{|c|}{ Fiducial limit (95\%) } \\
\hline & & & & Lower & Upper \\
\hline \multirow[t]{4}{*}{ B. bassiana } & $1 \times 10^{4}$ & $38.33(38.14)^{\mathrm{c}}$ & \multirow[t]{4}{*}{$6.06 \times 10^{5}$} & \multirow[t]{4}{*}{4.51} & \multirow[t]{4}{*}{8.14} \\
\hline & $1 \times 10^{6}$ & $51.67(45.96)^{b}$ & & & \\
\hline & $1 \times 10^{8}$ & $71.66(58.00)^{\mathrm{a}}$ & & & \\
\hline & Control & $0.00(0.36)^{d}$ & & & \\
\hline \multirow[t]{4}{*}{ M. anisopliae } & $1 \times 10^{4}$ & $36.66(37.22)^{b}$ & \multirow[t]{4}{*}{$1.52 \times 10^{7}$} & \multirow[t]{4}{*}{1.10} & \multirow[t]{4}{*}{2.09} \\
\hline & $1 \times 10^{6}$ & $41.66(40.10)^{b}$ & & & \\
\hline & $1 \times 10^{8}$ & $53.33(46.92)^{\mathrm{a}}$ & & & \\
\hline & Control & $0.00(0.36)^{\mathrm{c}}$ & & & \\
\hline \multirow[t]{4}{*}{ L. lecanii } & $1 \times 10^{4}$ & $50.00(44.99)^{\mathrm{c}}$ & \multirow[t]{4}{*}{$1.83 \times 10^{4}$} & \multirow[t]{4}{*}{4.25} & \multirow[t]{4}{*}{7.85} \\
\hline & $1 \times 10^{6}$ & $61.66(51.85)^{b}$ & & & \\
\hline & $1 \times 10^{8}$ & $85.00(67.74)^{\mathrm{a}}$ & & & \\
\hline & Control & $0.00(0.36)^{\mathrm{d}}$ & & & \\
\hline
\end{tabular}

Mean of six replications. Values in parentheses are arcsine transformed.

Means in a column followed by same superscripts are not significantly different according to DMRT at $\mathrm{P} \leq 0.05$.

Table.2 Time mortality response of entomopathogenic fungi against A. biguttula biguttula

\begin{tabular}{|c|c|c|c|c|}
\hline \multirow{2}{*}{$\begin{array}{c}\text { Entomopathogenic } \\
\text { Fungi }\end{array}$} & \multirow{2}{*}{$\begin{array}{c}\text { Conidial } \\
\text { concentrations } \\
\text { (Spores/ml) }\end{array}$} & \multirow[t]{2}{*}{$\mathbf{L T}_{\mathbf{5 0}}(\mathrm{h})$} & \multicolumn{2}{|c|}{ Fiducial limit (95\%) } \\
\hline & & & Lower & Upper \\
\hline \multirow[t]{4}{*}{ B. bassiana } & $1 \times 10^{4}$ & 300.39 & 134.64 & 670.22 \\
\hline & $1 \times 10^{6}$ & 247.49 & 136.011 & 450.35 \\
\hline & $1 \times 10^{8}$ & 164.18 & 123.34 & 218.54 \\
\hline & Control & 0.00 & 0.00 & 0.00 \\
\hline \multirow[t]{4}{*}{ M. anisopliae } & $1 X 10^{4}$ & 268.88 & 140.11 & 515.99 \\
\hline & $1 \times 10^{6}$ & 246.36 & 138.45 & 438.37 \\
\hline & $1 \times 10^{8}$ & 210.21 & 134.84 & 327.70 \\
\hline & Control & 0.00 & 0.00 & 0.00 \\
\hline \multirow[t]{4}{*}{ L. lecanii } & $1 \times 10^{4}$ & 228.11 & 138.20 & 376.51 \\
\hline & $1 \times 10^{6}$ & 196.34 & 130.80 & 294.73 \\
\hline & $1 \times 10^{8}$ & 115.37 & 96.26 & 138.28 \\
\hline & Control & 0.00 & 0.00 & 0.00 \\
\hline
\end{tabular}

*Mean of six replication 
Table.3 In vitro efficacy of bio control agents against cotton leafhoppers

\begin{tabular}{|c|c|c|c|c|}
\hline \multirow[t]{2}{*}{ Treatment } & 5 DAS & $10 \mathrm{DAS}$ & 15DAS & \multirow[t]{2}{*}{ Mean } \\
\hline & \% Mortality & \% Mortality & \% Mortality & \\
\hline $\mathrm{T}_{1}$-Chrysoperla@100000/ha & $\begin{array}{c}20.00 \\
(26.57)^{\mathrm{c}}\end{array}$ & $\begin{array}{c}67.50 \\
(55.24)^{\mathrm{bc}}\end{array}$ & $\begin{array}{c}80.00 \\
(63.43)^{\mathrm{bc}}\end{array}$ & $\begin{array}{c}55.83 \\
(48.35)^{\mathrm{bc}}\end{array}$ \\
\hline $\begin{array}{l}\mathrm{T}_{2}-\text { Lecanicilium lecanii } 1 \times 10^{8} \\
\text { spores } \mathrm{l}^{-1} \text { alone }\end{array}$ & $\begin{array}{c}42.50 \\
(40.69)^{\mathrm{b}}\end{array}$ & $\begin{array}{c}77.50 \\
(61.68)^{b}\end{array}$ & $\begin{array}{c}87.50 \\
(69.30)^{\mathrm{b}}\end{array}$ & $\begin{array}{c}69.17 \\
(56.27)^{\mathrm{b}}\end{array}$ \\
\hline $\begin{array}{l}\mathrm{T}_{3}-\text { Metarhizium anisopliae } 1 \times 10^{8} \\
\text { spores } \mathrm{l}^{-1} \text { alone }\end{array}$ & $\begin{array}{c}12.50 \\
(20.70)^{\mathrm{cd}}\end{array}$ & $\begin{array}{c}45.00 \\
(42.13)^{\mathrm{d}}\end{array}$ & $\begin{array}{c}57.50 \\
(49.31)^{\mathrm{d}}\end{array}$ & $\begin{array}{c}38.33 \\
(38.25)^{\mathrm{d}}\end{array}$ \\
\hline $\begin{array}{l}\mathrm{T}_{4}-\text { Beauveria bassiana } 1 \times 10^{8} \\
\text { spores } \mathrm{ml}^{-1} \text { alone }\end{array}$ & $\begin{array}{c}17.50 \\
(24.73)^{\mathrm{c}}\end{array}$ & $\begin{array}{l}60.00 \\
(50.77)^{\mathrm{c}}\end{array}$ & $\begin{array}{l}67.50 \\
(55.24)^{\mathrm{cd}}\end{array}$ & $\begin{array}{c}48.33 \\
(44.04)^{\mathrm{cd}}\end{array}$ \\
\hline $\begin{array}{l}T_{5} \text { - Fungi combination }\left(T_{1+} T_{2+}\right. \\
\left.T_{3}\right)\end{array}$ & $\begin{array}{l}15.00 \\
(22.79)^{\mathrm{c}}\end{array}$ & $\begin{array}{l}62.50 \\
(52.24)^{\mathrm{c}}\end{array}$ & $\begin{array}{c}62.50 \\
(52.24)^{\mathrm{d}}\end{array}$ & $\begin{array}{c}46.67 \\
(43.09)^{\mathrm{d}}\end{array}$ \\
\hline $\begin{array}{l}\mathrm{T}_{6}-\text { Imidacloprid 200SL @ } 100 \\
\mathrm{ml} / \mathrm{ha}\end{array}$ & $\begin{array}{l}97.50 \\
(80.90)^{\mathrm{a}}\end{array}$ & $\begin{array}{c}97.50 \\
(80.90)^{\mathrm{a}}\end{array}$ & $\begin{array}{l}97.50 \\
(80.90)^{\mathrm{a}}\end{array}$ & $\begin{array}{c}97.50 \\
(80.90)^{\mathrm{a}}\end{array}$ \\
\hline $\mathbf{T}_{7}-$ Control & 0.00 & 0.00 & 0.00 & 0.00 \\
\hline
\end{tabular}

Means of four replications, Figures in parentheses are arcsine transformed value

The results of in vitro efficacy of bio control agents on the reduction of cotton leafhoppers are presented in Table 3. In this, imidacloprid 200SL $(100 \mathrm{ml} / \mathrm{ha})$ was the most effective to control the cotton leafhopper which recorded 97.50 per cent mortality and it was significantly different from other treatments. Among the bio-control agents, L. lecanii was the most effective in reducing cotton leafhoppers compared with other bio-control agents which recorded per cent mortality of $42.50,77.50$ and 87.50 after the $5^{\text {th }}, 10^{\text {th }}$ and $15^{\text {th }}$ days of spray respectively with average of 69.17 per cent followed by $C$. zastrowii, $B$. bassiana and fungi combination with average per cent mortality of 55.83, 48.33 and 46.67 respectively (Fig. 1). Anitha (2007), reported that neem oil and Verticilium lecanii were the next best treatments after oxydemeton methyl. Harichandra naik and Shekharappa (2008), who reported Beauveria bassiana oil and Metarhizium anisopliae oil and their WP formulations and recorded 96.67 per cent mortality of leafhoppers at 10 DAT and Lecanicillum lecanii oil and B.bassiana WP formulations recorded $93.33 \%$ mortality at the concentration of $1 \times 10^{8}$ spores $/ \mathrm{ml}$. The lower efficacy was recorded in $M$. anisopliae with per cent mortality of $12.50,45.00$ and 57.50 after the $5^{\text {th }}, 10^{\text {th }}$ and $15^{\text {th }}$ days of spray respectively with average of 38.33 per cent mortality. Harichandra and Shekarappa (2009) reported that, application of Verticilium lecanii, Beauveria bassiana and Metarhizium anisopliae, were effective in reducing the leaf hopper population but were inferior to chemical control.

From the results obtained, among various concentrations, $1 \times 10^{8}$ spores $/ \mathrm{ml}$ recorded the highest per cent mortality and proved its best performance against the target insects. Hence the L. lecanii and Chrysoperla could be suggested in managing the target insect population.

\section{Acknowledgement}

The authors are grateful to Department of Agricultural Entomology and Department of plant pathology, TNAU, Coimbatore for providing entomopathogenic fungi and necessary facilities for carrying out this research. 


\section{References}

Abbas, M.A., 2001. General Agriculture. Publication Emporium 2nd edition Pakistan. Pp. 352.

Ahmad, M. and Khan, M. R., 1991. Insecticide resistance management strategies in cotton pests in Pakistan. Pakistan Ent., 13:1-4.

Ali, A., 1992. Physio-chemical factors affecting resistance in cotton against jassid, Amrasca devastans (Dist.) and thrips, Thrips tabaci (Lind.) in Punjab, Pakistan. Ph.D Thesis, Dept. Entomol, Univ Agric., Faisalabad. 430.

Anitha Bharath, K., 2005. Preliminary evaluation of commercial bio pesticides against selected insect pests. M.Sc. (Ag.) Thesis, Annamalai Univ., Annamalainagar, India.

Ansari, M.A., Vestergaard, S., Tirry, L. and Moensa, M., 2004. Selection of a highly virulent fungal isolates, Metarhizium anisopliae CLO 53, for controlling Hoplia philanthus. J. Inverteb. Pathol., 85: 89-96.

Arif, M. J., Abbas, G. and Saeed, S., 2007. Cotton in danger, p: 4. Dawn, The Internet Edition (http://DAWN.com), March 24th, 2007.

El-Sinary, G.H., 2002. Influence of the entomopathogenic fungus, Beauveria bassiana (Balsamo) on the mature larvae of the potato tuber moth, Phthorimaea operculella (Zeller) under different degrees of temperature and relatively humidity. J. Agric. Sci., Mansoura Univ., 27: 4151-4161.

Harichandra Naik, P.R. and Shekharappa,
2009. Field evaluation of different entomopathogenic fungal formulations against sucking pest of okra. Karnataka J. Agric. Sci.22: 575-578.

Harichandra Naik, R. and Shekharappa, 2008. In vitro evaluation of entomopathogenic fungal formulations against sucking insect pests of okra. Karnataka J. Agric. Sci., 22 (4): 784-786

Karthikeyan, A. and Selvanarayanan, V., 2011. In vitro Efficacy of Beauveria bassiana (Bals.) Vuill. and Verticillium lecanii (Zimm.) viegas against selected insect pests of cotton. Recent Research in Science and Technology, 3(2): 142143.

Liu, H., Skinner, M., Parker, B.L. and Brownbridge, M., 2002. Pathogenicity of Beauveria bassiana, Metarhizium anisopliae (Deuteromycotina: Hyphomycetes), and other entomopathogenic fungi against Lygus lineolaris (Hemiptera: Mirridae). $J$. econ. Entomol., 95: 675-681.

Quesada-Moraga, E., Carrasco-Diaz, J. A. and Santiago-Alvarez, S., 2006. Insecticidal and antifeedant activities of proteins secreted by entomopathogenic fungi against Spodoptera littoralis (Lepidoptera: Noctuidae). J. Appl. Entomol., 130: 442-452.

Sorejani, M., 1998. Current trend in pesticide usage in some Asian countries. Rev. Appl. Entomo., 77: 219-234.

Wright, M.S., Raina, A.K. and Lax, A.R., 2005. A strain of the fungus Metarhizium anisopliae for controlling subterranean termites. J. econ. Entomol., 98: 14511458.

\section{How to cite this article:}

Manivannan, A., R. Philip Sridhar, A. Kamalakannan, N. Ganapathy and Karthikeyan, S. 2018. In vitro Efficacy of Bio Control Agents against Cotton Leafhopper, Amrasca biguttula biguttula (Ishida) (Homoptera: Cicadellidae). Int.J.Curr.Microbiol.App.Sci. 7(09): 2026-2031. doi: https://doi.org/10.20546/ijcmas.2018.709.245 